\title{
DOI 10.26886/2520-7474.2(28)2018.9
}

\section{UDC: $393.05: 130.2$}

\section{FUNERAL CEREMONY IN THE SYSTEM}

\section{OF STRUCTURAL-FUNCTIONAL STUDIES OF FAMILY OBJECTIVES}

\section{O. Kukharenko, PhD in Philological Sciences}

Kharkiv State Academy of Culture, Ukraine, Kharkiv

On the basis of the author's proposed division of the cycle of traditional funeral ceremonies into episodes, a broad perspective for further research is revealed. The criteria of the division of the cycle and each ritual into episodes are considered, in particular, the material-spiritual metamorphosis of the characters of the sacral action. In connection with this criteria, changes in social statuses, compositional construction, deployment and involvement of new participants in sacralization, as well as the relationship with the afterlife, are studied. Structural-functional method is used; the construction of the structure opens up the possibility for researchers to look considerably more widely on the connection between the individual rituals of the cycle, to compare the burial ritual with family and the calendar cycle rituals, etc.

Key words: rituals of transition, national family ritual, structuralfunctional method, traditional funeral ritual.

кандидат фрілологічних наук, Кухаренко О. О. Поховальні обряди в системі структурно-функціональних досліджень родинної обрядовості / Харківська державна академія культури, Україна, Харків

На основі запропонованої автором структури поділу циклу традиційних поховальних обрядів на епізоди означено перспективу щодо подальших досліджень. Розглядаються критерії членування циклу й кожного обряду на епізоди, зокрема матеріально-духовна метаморфоза персонажів сакральної дії. У зв'язку з указаним 
критерієм, досліджуються зміни соціальних статусів, композиція, розгортання й залучення нових учасників до сакралізації, а також зв'язок із потойбіччям. Використано структурно-функціональний метод; побудова структури відкриває перед дослідниками можливість значно ширше розглянути зв'язки між окремими обрядами циклу, порівняти поховання з іншими родинними й календарними обрядами тощо.

Ключові слова: обряди переходу, національна родинна обрядовість, структурно-фрункціональний метод, традиційний поховальний обряд.

Вступ. Поховальний обряд $€$ достатньо вивченим у царині етнологічних студій, але культурологічні його дослідження з точки зору структурно-функціонального аналізу мають значні перспективи. Створення структури дозволяє значно ширше розглянути зв'язки між обрядами циклу, порівняти поховання з іншими обрядами родинного та календарного циклу тощо.

Національні обряди, зокрема поховальні, на сучасному етапі досліджують В. Балушок, О. Боряк, І. Ігнатенко, Г. Кабакова, О. Кісь, С. Лащенко, М. Маєрчик, Н. Пушкарьова. Структурно-фрункціональний і структурно-семантичний методи дослідження обрядовості використовували А. Байбурін, К. Леві-Строс, В. Пропп, В. Топоров, Б. Успенський. Стаття $є$ своєрідним продовженням публікацій автора, присвячених структурі циклу весільних обрядів та її дослідженню [3, с. 10-17]. Поховальний обряд, що також входить до складу родинної обрядовості, можна досліджувати аналогічним чином.

Формулювання мети статті й завдань: дослідити критерії поділу структури поховального обряду на епізоди як складові обрядової дії та визначити взаємозв'язки іï з обрядами переходу, що становлять 
процес змін соціальних статусів головного об'єкта, над яким здійснюються традиційні обрядові дійства; означити розширення меж сакралізації та ії залежність від композиційної побудови обрядових сюжетів.

Виклад основного матеріалу статті. Як і згадана структура обрядового циклу українського весілля, так і структура поховального обряду складається з певної послідовності епізодів та є поліепізодною чи поліелементною. Критеріями членування складових на менші структурні одиниці - епізоди - $є$ такі ознаки: 1) новорівневий, узагальнюючий повтор події; 2) матеріально-духовна метаморфоза персонажів сакральної дії; 3) зміна сакрального хронотопа; 4) принцип постійного оновлення. Наявність указаних ознак, або хоча б однієї 3 них означає перехід від одного епізоду до іншого в межах переходу від однієї складової до іншої. Перша ознака пов'язана зі спостереженням, що обрядові дії, в тому числі й похоронні обряди, складаються 3 обмеженої кількості дій, які час від часу повторюються; але повторюються на значно вищому рівні 3 наростаючим рівнем сакралізації. Максимально наближеною до цієї є четверта ознака, заснована на принципі постійного оновлення. Це природно, оскільки повернення час від часу до однієї й тієї самої дії має відбуватися шляхом оновлення ситуації як складової поховального обряду. Під зміною сакрального хронотопа - третя ознака поділу на епізоди - слід вважати розширення місця обрядових дій у залежності від часу їхнього проведення. Розширення хронотопа вступає у пряму залежність від рівня сакралізації дій, предметів і явищ: чим більший простір залучається до дії, тим вищий рівень сакралізації всього, що ця дія використовує.

Оскільки в одній статті розглянути кожну з указаних ознак неможливо, детально охарактеризуємо лише одну, присвячену 
матеріально-духовній метаморфозі головного персонажа сакральної дії. Ідеться, згідно з концепцією Арнольда ван Геннепа, про певні етапи переходу [2, с. 9; 4, с. 51], які необхідно подолати головному об'єктові від стану помираючого до стану покійного. Таких статусів, досить умовних, існує близько шести - за кількістю обрядів, що становлять поховальний цикл, окрім післяпоховальних. Помираючий - мрець - тіло - небіжчик - похований - покійний; це перелік статусів, яких має досягти об'єкт обрядового циклу в результаті виконання традиційних сакральних дійств. Крім того, відбувається перехід інших учасників обряду, зокрема членів сім'ї (дружина - вдова, діти - сироти), але лише тоді, коли персонаж помирає.

Слід зазначити, що фракт настання смерті $€$ менше значимим за обрядові дійства з цього приводу; померлий не вважається таким до того часу, поки над ним не виконають необхідних обрядових дій. Початкова ситуація похорону $€$ порушенням відповідності між соціальним і біологічним станом людини; фрізична смерть не рівнозначна соціальній, обряд має усунути цю нерівнозначність [1, с. 101]. Але під час поховального обряду чи радше поховальних обрядів, що становлять обрядовий цикл, об'єкт долає не один, а кілька переходів; після кожного обряду, в результаті їх проведення, він набуває іншого статусу. Перехід від життя до смерті, від реального до надприродного, від цього світу до потойбіччя відбувається поступово чи покроково.

Цілком прогнозованим і значно очевиднішим у структурі поховальних обрядів, ніж у весільному циклі, $\epsilon$ наявність прологу, в якому ще жива особа має померти, щоб над нею почали здійснювати відповідні обряди. Такий пролог вважається окремим обрядом, оскільки в ньому наявні сакральні дії учасників: запрошення священика 3 останніми дарами, здійснення таїнства причащання, відхід 
помираючого зі свічкою-громницею в руках, повідомлення пономаря про смерть односельця, подзвін за душею новопреставленого. Стисло перелічено всі дії прологу, а після їх завершення той, що помирає, здійснює перший перехід зі статусу помираючого до статусу мерця.

Іншими обрядами поховального циклу є підготовка до поховання, яку ще називають «стерегти душу», похорон удома й поховання на кладовищі, поминальний обід і обрядові дії, умовно названі післяпоховальними, серед них обряд будіння покійника, третини чи дев'ятини, сороковини й інші поминальні дні родинного та календарного циклів.

Обряд підготовки до поховання мерця містить такі епізоди: мерця омивають, одягають у приготовлений «на смерть» одяг і кладуть на лаву під ту стіну, де є два вікна; на вікно в посудині ставлять воду для душі - умиватися й пити; близькі та сусіди ввечері й уночі «стережуть душу»; молодь улаштовує нічні забави в хаті мерця. У результаті цього обряду відбувається метаморфоза, під час якої мрець стає тілом; це перехідний етап між статусом мерця й небіжчика. Вибір назви «тіло» на даному етапі полягає у віруваннях про знаходження поруч душі, котра покинула тіло й саме «тіло» $є$ те, що залишилося від поєднання двох складових. Також забави в хаті мерця влаштовуються саме 3 «тілом», як називають те, на що перетворилася, трансформувалася жива колись людина. Усі наступні статуси свідчать про зростаючий вплив сакралізації на профранні речі та уявлення. Із попередніх досліджень відомо, що сакралізація при розгортанні підпорядковує собі нові території за певні одиниці часу - розширення хронотопа, а також залучає до дії дедалі більшої кількості учасників.

Як зазначалося, тіло має стати небіжчиком після завершення похорону, що триває всю першу половину наступного після смерті дня в домі померлого. До епізодів, що становлять обряд похорону, 
належать такі: односельці зранку сходяться робити труну й копати яму; домовину вносять до хати й ставлять поруч із тілом; священик править «велику» службу в хаті біля тіла; після кроплення труни близькі родичі кладуть до неї тіло й виносять домовину з хати; виносячи, тричі стукають труною об поріг чи одвірки, оселю осипають житом; на подвір'я виносять постіль, що лежала на лаві під мерцем; на кришку труни кладуть рушник і хліб; після виносу домовини з двору замикають хату, а ворота зав'язують червоним поясом чи рушником; односельці супроводжують небіжчика на цвинтар; дорогою літня баба йде за домовиною й роздає коржики з медом і бублики з маком.

Коли похоронна процесія виходить за подвір'я, відбувається розширення хронотопа й до обрядової дії долучається нова частка простору: сільська вулиця, що веде на кладовище, й сам цвинтар. Після прибуття туди розпочинається наступний обряд - поховання, який містить такі епізоди: на кладовищі біля викопаної ями священик править «малу» службу; присутні прощаються з небіжчиком; труну забивають цвяхами й на сувоях полотна чи рушниках опускають у яму; священик «запечатує» могилу; односельці кидають до ями по три пригоршні землі; родичі запрошують присутніх на обід; учасники обряду повертаються до двору похованого; на цвинтарі копачі насипають могилу й установлюють хрест. Слід вказати, що перехід статусу небіжчика в статус похованого відбувається в результаті проведеного обряду поховання, але зміна ця, як і в усіх попередніх випадках, відбувається не після обряду, а в середині його структури відразу після кульмінаційного епізоду. Для того, щоб небіжчик вважався похованим, священик має «запечатати» могилу: саме цей епізод є кульмінацією означеного обряду.

Це дійство, як і наступний обряд - поминальний обід, відбуваються в другій половині дня поховання; його завдання - зміна статусу 
похованого, він має стати покійником чи покійним. Новий статус близький до терміну «заспокоїтися» й така спорідненість не $€$ випадковою, оскільки похований, згідно з критеріями первісного мислення, дійсно повинен заспокоїтися й позбавитися життєвих проблем цього світу, які супроводжували його до смерті; заспокоїтися й погодитися з тим, що все залишене ним надалі належатиме спадкоємцям; заспокоїтися й прийняти як даність його перебування на тому світі - належність до потойбіччя. Але для того, щоб небіжчик потрапив на той світ, недостатньо його просто закопати в землю на кладовищі. У результаті обряду має відкритися вхід до потойбіччя саме заради цього й здійснюється обряд; а з відкриттям входу елементи потойбічного світу проявляються в реальності в сакралізації звичайних дій і предметів, які в результаті обряду стають сакралізованими, сакральними, а отже незвичайними. У цьому полягає сенс будь-якого обряду, й родинний обрядовий цикл - не виняток із цього правила.

Запропонована структура зміни статусу головного об'єкта похоронних обрядів не є загальноприйнятою. Ії мета - позначити кожен обряд як перехід до наступного статусу. Те, що під час прологу жива людина, помираючи, змінює статус на мерця, закономірно й не потребує додаткових пояснень. До цього можна додати хіба що синоніми до слова мрець, такі як мертвий, померлий, мертвяк. Під час обряду підготовки до поховання спостерігається наступна трансформація: обрядові дії відбуваються з тілом померлого. А в цей самий час десь поруч перебуває душа, що періодично навідує тіло, 3 яким недавно становила єдине ціле. Після того, як тіло омите, одягнене в завчасно приготований одяг, забезпечене домовиною, воно набуває статусу небіжчика, готового до поховання. Черговий обряд переводить небіжчика в статус похованого, але для того, щоб набути 
статусу покійного, іншими словами - заспокоїтися, знайти спокій, необхідно здійснити ще один обряд - поминальний обід після поховання.

Указаний обряд, як зазначалося, відбувається в день поховання, після повернення 3 кладовища; він є п'ятим у циклі поховальних обрядів, якщо пролог, під час якого людина помирає, вважати першим. До поминального обіду належать такі епізоди: учасники обряду миють руки перед воротами обійстя і входять до двору та хати; присутні куштують по три ложки куті й сідають за столи; священик виголошує молитву, після чого розпочинається обід; представник рідні підносить присутнім по чарці горілки; старців годують надворі; після обіду господарі розраховуються з церковним причтом грошима та хлібом; учасники обіду повертаються до власних домівок.

Зазначалося, що зміна статусу головного об'єкта, а часто й інших учасників обряду, має відбуватися в кульмінаційному моменті всього дійства. Щоб визначити його, слід встановити, на якому етапі втручання потойбічного до буденної реальності найзначніше, де сакралізація дій і предметів сягає найвищої точки розвитку. До таких належить два епізоди - вживання учасниками обрядової їжі й виголошення священиком молитви. Стосовно другого епізоду слід розуміти, що християнські елементи нашарування на давньому похоронному обряді $€$ значно пізнішими за сам обряд і місію православного священика в дохристиянські часи виконував інший служник іншого культу. До того ж, виголошувати молитву й благословляти їжу - звична релігійна практика, з чого можна зробити висновок, що священик просто благословляє ті страви, які учасники споживатимуть.

Але не можна не помітити дивної ситуації: обрядову кутю, по три ложки за упокій померлого, присутні на обіді споживають без 
попереднього благословення. Уся їжа, що призначена для обіду, благословляється й лише одна страва не піддається такій процедурі; не піддається тому, що вживається вона до обіду й до молитви, що благословляє їжу. Можливо це відбувається тому, що цю страву не можна благословляти, вона належить іншому світові та має на собі певні ознаки максимальної сакралізації?

У цьому моменті дослідження доречно звернутися до праці В. Проппа «Історичні корені чарівної казки», де зазначено, що казковий герой, подорожуючи в тридев'яте царство, намагається потрапити до потойбіччя, щоб повернути свою кохану чи іншу близьку людину, котра насправді не була викрадена надприродною істотою, а померла. Виявляється, що потрапити на той світ, попередньо не померши, надзвичайно непросто й на це здатні лише обрані - головні персонажі чарівних казок, але й вони потребують певної допомоги. Згідно 3 сюжетом, таким помічником виступає баба-яга, яка, окрім іншого, годує героя спеціальною їжею, без якої до потойбіччя потрапити неможливо. «Мотив пригощання героя ягою на його шляху до тридесятого царства склався на основі уявлення про чарівну їжу, що споживає померлий на шляху до потойбічного світу» [5, с. 162]. Зазвичай такої їжі живим людям вживати не можна, але під час сакралізації в момент відкриття входу до потойбічного світу, тимчасово скасовуються найсуворіші заборони, відміняються табу. А оскільки Пропп зазначає, що казка зберегла елементи багатьох обрядів і звичаїв $[5$, с. 119] кульмінаційним епізодом під час поминального обіду таким чином $є$ та подія, де учасники вживають обрядову їжу - поминальну кутю, щоб допомогти небіжчикові, закопаному на кладовищі, потрапити до потойбіччя й перетворитися з похованого на покійного. А це означає, що заспокоїтися він може лише за умови потрапляння на той світ місця свого остаточного перебування. 
Як указувалося, потрапити туди - нелегке завдання, навіть для померлого; навіть якщо учасники обряду роблять усе, щоб допомогти йому в цьому. Але й після таких дій немає остаточної впевненості, що перехід відбувся, похований не застряг між світами, що він зможе заспокоїтися, не повертатиметься й не мститиметься родичам. Тому всі обряди так званого післяпоховального циклу мали на меті не лише вшанувати померлих предків, а й повторити, вдосконалити, закріпити момент переходу похованого до потойбіччя. До таких обрядів належать (оскільки поминальний обід у структурі $€$ п'ятим, наступні дійства подаємо як продовження обрядового циклу): 6) обряд розбудження покійника - на ранок наступного після похорону дня близькі та родичі йдуть на цвинтар «будити» покійного - навідати могилу. Після цього прямують до хати покійного на поминальне снідання, де споживають ті самі страви, що й на поминальному обіді; 7) третини чи дев'ятини обряд, який виконується залежно від регіону на третій день після похорону чи сьомий після відходу душі. У церкву несуть хліб і мед, замовляють службу. Удома - поминальний обід для родичів, запрошених друзів і сусідів; 8) сороковини - той самий поминальний обід відбувається вже на сороковий день, з обов'язковим коливом і запрошеними найближчими до покійника людьми; 9) інші поминальні дні родинного та календарного циклів - прийнято поминати покійного за півроку та за рік, але не після цієї дати, а напередодні, як правило, в суботу, у визначений церквою поминальний день. Існує немало поминальних субот і в календарній обрядовості, під час яких обряд може повторюватися ідентично до перелічених вище або дещо спрощено. Але пильне спостереження за всіма цими обрядовими діями доводить - усі вони є поминальними та складаються з відвідин могили, церкви й обіду для родичів, друзів і сусідів покійного; а отже, не чим іншим, як повторенням поминального обіду, який відбувається після 
поховання в день похорону. Отже, означені обряди ні поділу на епізоди, ні окремого детального розгляду не потребують.

Висновки. Структура циклу поховальних обрядів $є$ поліепізодною й це дослідження присвячується лише одній 3 чотирьох ознак членування обряду на епізоди - матеріально-духовній метаморфозі головного об'єкта. Протягом п'яти обрядів налічується така сама кількість статусів, яких набуває: помираючий: мрець - тіло - небіжчик похований - покійний.

Наявність прологу в структурі поховальних обрядів $є$ очевиднішою, ніж у весільному циклі, при цьому його слід уважати окремим і цілісним обрядом. Окрім прологу, до основних обрядів циклу належать: приготування чи підготовка до поховання, домашній обряд похорону, поховання на кладовищі, поминальний обід. Головними ознаками переходу від одного обряду до іншого $\epsilon$ розширення геограсрії хронотопа й наростаючий вплив сакралізації на профанні речі та уявлення. Починаючи з поминального обіду відбувається завершення того й іншого, а цикл післяпоховальних обрядів, значно розтягнутий у часі, остаточно згортає сакральне на користь профранного відбувається вихід з обряду. Значна роль у сприйнятті ритуальних дійств на рівні первісного мислення належить родючості, зокрема ії сакралізації, та взаємодії з потойбічним світом.

\section{תimepamypa:}

1. Байбурин А. К. Ритуал в традиционной культуре / А. К. Байбурин. СПб.: Наука, 1993. - 238 с.

2. Геннеп ван A. Обряды перехода (систематическое изучение обрядов) / Арнольд ван Геннеп; пер. с фрр. - М. : Восточ. лит-ра, 1999. $-175 c$. 
3. Кухаренко О. О. Побудова структури української весільної обрядовості / Кухаренко О. О. // Парадигма пізнання: гуманітарні питання. - Київ, 2016. - № 7. - C. 5-18.

4. Маєрчик М. С. Ритуал і тіло. Структурно-семантичний аналіз українських обрядів родинного циклу / Марія Маєрчик. - Київ: Критика, 2011. - 326 с.

5. Пропп В. Я. Исторические корни волшебной сказки / В. Я. Пропп. М.: Лабиринт, 2000. - 336 с.

\section{References:}

1. Bayburin A. K. Ritual v traditsionnoy kulture / A. K. Bayburin. - SPb.: Nauka. 1993. - 238 C.

2. Gennep van A. Obriady perekhoda (sistemnoe izuchenie obriadov) / Arnold van Gennep; per. s fr. - M: Vostoch. Lit-ra, 1999. - 175 s.

3. Kukharenko O. O. Pobudova struktury ukrainskoi vesilnoi obriadovosti / Kukharenko O. O. // Paradygma piznannia: gumanitarni pytannia. - Kyiv, 2016. - № 7. - S. 5-18.

4. Maierchyk M. S. Rytual i tilo. Strukturno-semantychnyi analiz ukrainskykh obriadiv rodynnogo tsyklu / Mariia Maierchyk. - Kyiv: Krytyka, 2011. $326 \mathrm{~s}$.

5. Propp V. Ya. Istoricheskie korni volshebnoi skazki / V. Ya. Propp. - M.: Labirint, 2000. - 336 s. 